\title{
Subjective ratings of health state and railway noise
}

\author{
Takumasa Yoshida* and Shin'ichi Nakamura** \\ *The Institute of Public Health, \\ 4-6-1, Shirokanedai, Minato-ku, Tokyo, 108 Japan \\ **The Tokyo Metropolitan Research Institute for Environmental Protection, \\ 1-7-5, Shin-suna, Koto-ku, Tokyo, 136 Japan
}

(Received 1 September 1987)

\begin{abstract}
Relationship between subjective ratings of health state and railway noise were investigated at fifteen sites in Tokyo. The inquiry was conducted for married women and 830 data were available for analyses. Relationships between subjective ratings of health state and answers to each question on objective disturbance were also ascertained in relation to noise levels. In the results, it was found that subjective ratings of health state were closely correlated to age and noise levels. Greater age and higher noise levels increased ill-health. Annoyance indicated no relation to subjective ratings of health state, whereas sleep disturbance, mental disturbance or physical symptoms indicated close relation to subjective ratings of health state. Noise higher than $70 \mathrm{~dB}(\mathrm{~A})$ accelerated increase of ill-health. Noise higher than $60 \mathrm{~dB}(\mathrm{~A})$ indicated increase of highly disturbed respondents to sleep disturbance, mental disturbance and physical symptoms. These results suggested that noise could cause ill-health in the meaning of subjective ratings of health state.
\end{abstract}

PACS number: 43. 50. Qp

\section{INTRODUCTION}

Noise can cause annoyance and interference with activities in daily lives of people, and it would be generally believed that these may lead to health disorders. Many researches were reported on increasing of cardiovascular diseases, nervous diseases and gastrointestinal diseases in rather serious noise area. ${ }^{1-6)}$ In these researches, subjective ratings of health state, subjective symptoms, medicament consumption and hospital admission rates were also investigated in relation to annoyance or disturbance due to noise. As for subjective ratings of health state, this is usually considered to be an endogenic factor contributing to annoyance or disturbance due to noise. For example, Gros et al. (1983) showed that subjective ratings of health state and demographic variables, especially age, correlated to factor scores in sleep quality. ${ }^{4}$ Francois (1980) reported that "good" health was not cor- related to annoyance, whereas subjective symptoms were correlated to annoyance. ${ }^{5)}$ Subjective ratings of health state is not so much in formal terms of definite illness, but rather in feelings of fatigue, malaise and general loss of well-being. Nevertheless, subjective ratings of health state in relation to noise effects on man would be more important as well as definite illness, if health might be defined as maintenance of a state of physical, mental and social well-being. Then, it would be expected that noise, not even at extremely high levels, might increase ill-health in the meaning of subjective ratings of health state.

This study concerns to subjective ratings of health state of the inhabitants and noise of the ordinary railways in Tokyo, and also concerns to relationships between subjective ratings of health state and each of annoyance, speech interference, sleep disturbance, mental disturbance or physical symptoms in relation to noise of railways. Further, it aims to obtain a 
critical noise level in relation to subjective ratings of health state.

\section{INQUIRY AND NOISE}

Fifteen sites in Tokyo were investigated, where each site had area of about 2 ha along each $200 \mathrm{~m}$ of the railways. These sites were selected in taking account of such factors of rate of building area (Japanese National Building Act), numbers of tracks of railways, and structures of railways and numbers of trains passing through per day. The characteristics of the selected sites are shown in Table 1. An inquiry was conducted for 1,123 women and data of 830 were available for the followed analyses. Table 2 shows endogenic factors of the women inquired that contained age, occupation, numbers of family, years of residence and occupation of their husbands. Noise levels were estimated in $\mathrm{dB}(\mathrm{A})$ of $L_{\text {eq }}$ (equivalent sound level), $L_{\mathrm{dn}}$ (day and night sound level) and $L_{\mathrm{m}}$ (energy-means of sound levels at peaks) for $24 \mathrm{~h}$. These data were obtained by measuring at representative points in each site. ${ }^{7)}$
Table 3 shows the main questions in this inquiry. It included questions relating to total feelings on "annoyance," "disturbance as a whole" and "dissatisfaction with noise environment," and objective disturbance of speech interference (listening to broadcast, conversation and telephoning), sleep disturbance (awakening, difficulty in getting to sleep), mental disturbance (irritation, startle, difficulty in thinking or reading, difficulty in relaxing), physical symptoms (gastroenterological disorder, tinnitus or earache, headache or feeling heavy in the head, palpitation of heart). "Annoyance" was inquired in seven-points scale denoted at both poles of "not at all annoyed" and "extremely annoyed." "Disturbance as a whole" was inquired in four categories ranging from "not disturbed" to "considerably disturbed." "Dissatisfaction with noise environment" was also inquired in four categories ranging from "satisfied" to "dissatisfied." The other questions relating to each objective disturbance of speech interference, sleep disturbance, mental disturbance and physical symptoms were inquired in

Table 1 Characteristics of the sites inquired and the railways.

\begin{tabular}{ccllclc}
\hline $\begin{array}{c}\text { No. } \\
\text { of } \\
\text { sites }\end{array}$ & $\begin{array}{c}\text { Numbers } \\
\text { of } \\
\text { samples }\end{array}$ & $\begin{array}{c}\text { Tracks } \\
\text { of } \\
\text { railways }\end{array}$ & $\begin{array}{c}\text { Flat or } \\
\text { concrete } \\
\text { bridge }\end{array}$ & $\begin{array}{c}\text { Numbers } \\
\text { passing } \\
\text { trains }\end{array}$ & $\begin{array}{c}\text { House- } \\
\text { density }\end{array}$ & $\begin{array}{c}\text { Class } \\
\text { of } \\
\text { area }\end{array}$ \\
\hline 1 & 62 & Single & Flat & $126 / \mathrm{d}$ & $41.0 / \mathrm{ha}$ & $\mathrm{A}$ \\
2 & 61 & Double & Flat & $135 / \mathrm{d}$ & $49.5 / \mathrm{ha}$ & $\mathrm{A}$ \\
3 & 69 & Single & Flat & $243 / \mathrm{d}$ & $52.0 / \mathrm{ha}$ & $\mathrm{A}$ \\
4 & 66 & Double & Flat & $364 / \mathrm{d}$ & $35.0 / \mathrm{ha}$ & $\mathrm{A}$ \\
5 & 65 & Double & Flat & $644 / \mathrm{d}$ & $51.0 / \mathrm{ha}$ & $\mathrm{A}$ \\
6 & 31 & Two P. & C.B. & $976 / \mathrm{d}$ & $42.0 / \mathrm{ha}$ & $\mathrm{A}$ \\
7 & 71 & Two P. & C.B. & $976 / \mathrm{d}$ & $43.5 / \mathrm{ha}$ & $\mathrm{A}$ \\
8 & 65 & Two P. & C.B. & $633 / \mathrm{d}$ & $80.0 / \mathrm{ha}$ & $\mathrm{B}$ \\
9 & 59 & Double & Flat & $637 / \mathrm{d}$ & $64.0 / \mathrm{ha}$ & $\mathrm{B}$ \\
10 & 49 & Double & Flat & $572 / \mathrm{d}$ & $67.0 / \mathrm{ha}$ & $\mathrm{C}$ \\
11 & 36 & Double & C.B. & $572 / \mathrm{d}$ & $61.5 / \mathrm{ha}$ & C \\
12 & 38 & Two P. & C.B. & $656 / \mathrm{d}$ & $56.0 / \mathrm{ha}$ & C \\
13 & 62 & Two P. & C.B. & $776 / \mathrm{d}$ & $65.5 / \mathrm{ha}$ & C \\
14 & 43 & Double & C.B. & $461 / \mathrm{d}$ & $79.0 / \mathrm{ha}$ & D \\
15 & 53 & Two P. & Flat & $852 / \mathrm{d}$ & $87.5 / \mathrm{ha}$ & D \\
\hline Total & 830 & & & & & \\
(Mean) & & & & $(574 / \mathrm{d})$ & $(58.5 / \mathrm{ha})$ & \\
\hline
\end{tabular}

Abb. (structures of railway), C.B.: concrete bridge, Two P.: two pairs of tracks of railway (classification of residential area is defined in The National Building Act of Japan), A: residential area of first class (limits of building-area rate $=30 \sim 60 \%$ ), B: residential area of second class (limit of building-area rate $=60 \%$ ), C: residential area of third class (limit of building-area rate $=60 \%$ ), $\mathrm{D}$ : area near commercial area (limit of building-area rate $=80 \%$ ). 


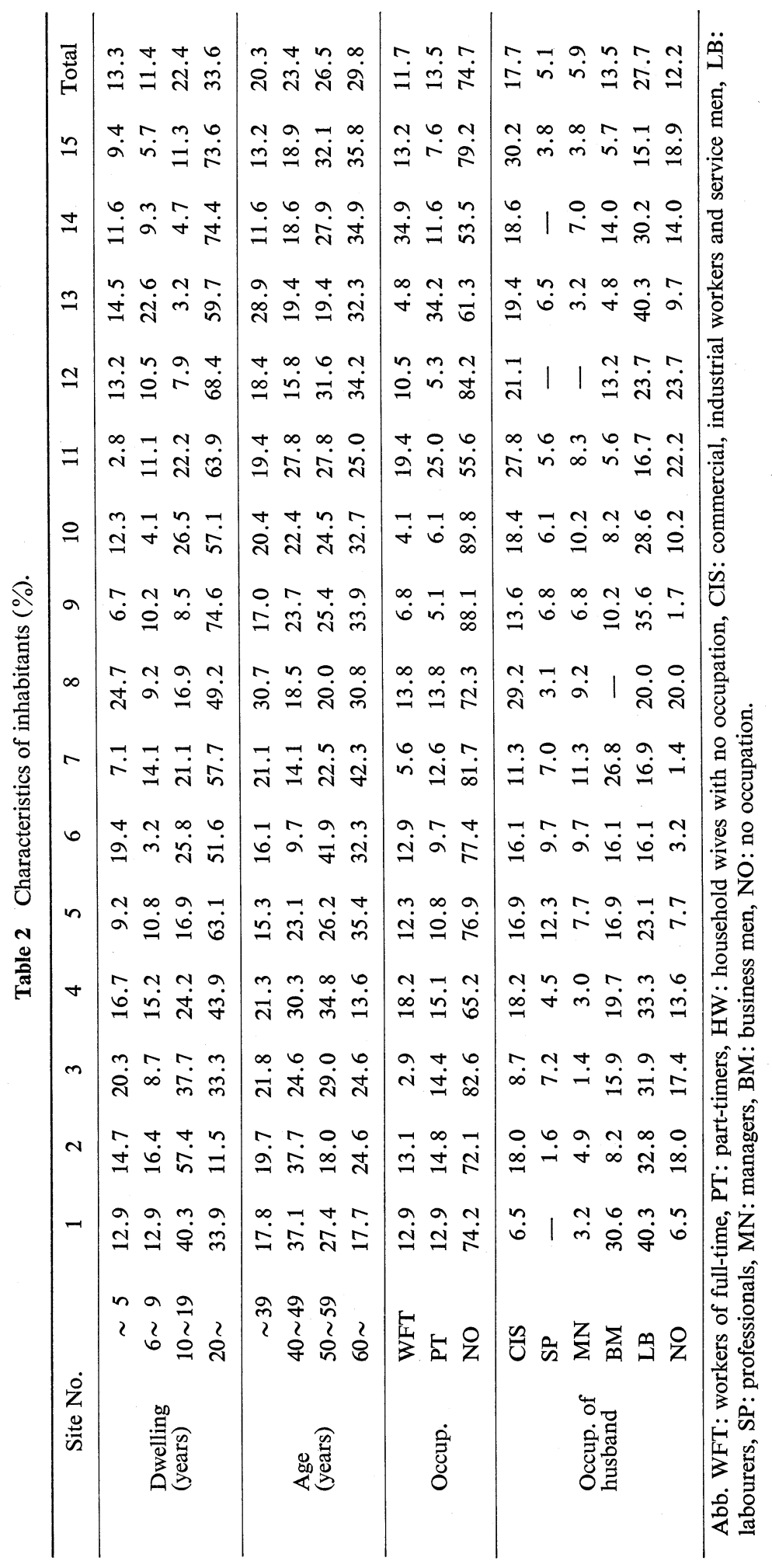


Table 3 Questions on disturbances due to noise.

\begin{tabular}{|c|c|}
\hline General feelings: & $\begin{array}{l}\text { Disturbance as a whole } \\
\text { Annoyance } \\
\text { Dissatisfaction with noise } \\
\text { environment }\end{array}$ \\
\hline Speech interference: & $\begin{array}{l}\text { TV-listening } \\
\text { Telephoning } \\
\text { Conversation }\end{array}$ \\
\hline Sleep disturbance: & $\begin{array}{l}\text { Awakening } \\
\text { Difficulty in getting to sleep }\end{array}$ \\
\hline Mental disturbance: & $\begin{array}{l}\text { Irritation } \\
\text { Startle } \\
\text { Difficulty in thinking or reading } \\
\text { Difficulty in relaxing }\end{array}$ \\
\hline Physical symptoms: & $\begin{array}{l}\text { Gastroenterological disorder } \\
\text { Tinnitus or earache } \\
\text { Headache or feeling heavy in } \\
\text { the head } \\
\text { Palpitation }\end{array}$ \\
\hline
\end{tabular}

five categories ranging from "almost never" disturbed (or suffered and felt) to "extremely often" disturbed. These questions on disturbance were inquired in relation to noise. Health states of the women were rated by themselves into three categories of "ill-health," "normal health" and "good health," that was inquired in face sheets.

\section{ANALYSES OF DATA}

For analyzing relationship between subjective ratings of health state and noise in taking account of endogenic factors (variables or items) of the women and the characteristics of the sites, Hayashi's quantification method II was used. In these analyses, health state was used as a outside item (a criterion variable). As multivariate analysis for qualitative data, this method has been known very powerful and profitable, that corresponds in a meaning to a methods of discrimination function with only dummy criterion variable and dummy predictor variables and that have been often used for analyzing data of questionnaires in Japan. ${ }^{8-10)}$ This method also produces estimated (or quantified) numerical values that have a common scale (with no dimension) for all of each category of predictor items (variables) and a criterion item. ${ }^{10 \text { ) }}$

In preliminary analyses, all items relating to the human factors and the sites were used as predictor items. Then, age, occupation, numbers of tracks of railways, occupation of their husbands were selected as statistically significant predictor items $(p<0.05)$. As for measures of noise levels, $L_{\mathrm{dn}}$ and $L_{\text {eq }}$ was also selected as a statistically significant predictor of noise levels in the preliminary analyses $(p<0.05) . \quad L_{\mathrm{dn}}$ was employed in the following analyses of this study, because the results when $L_{\mathrm{dn}}$ was used as a measure of the noise levels indicated higher correlation ratio than those when $L_{\text {eq }}$ was used.

In the next, independence between subjective ratings of health state and answers to the questions on each objective disturbance were examined respectively by using chi-square tests. ${ }^{11)}$ The following null-hypothesis was tested for each question on disturbance. $\mathrm{H}_{0}$ : the proportion of ill-health to "highly disturbed" respondents did not differ from the proportion of ill-health to the other respondents. $\mathrm{H}_{1}$ : the proportion of ill-health to "highly disturbed" respondents was higher than the proportion of illhealth to the other respondents. In these analyses, "highly disturbed" respondents were defined for each question on objective disturbance as follows; Ratings to 6 or 7 in "annoyance" of seven-points scale, answers to be "considerably disturbed" in "disturbance as a whole" of four categories, answers to be "dissatisfied" in "dissatisfaction with noise environment" of four categories, and answers to be "considerably or extremely often" disturbed in each question of five categories on speech interference, sleep disturbance, mental disturbance and physical symptoms. The categories of subjective ratings of health state were adjusted into two categories of ill-health and the others (normal and good health) for the tests. Further, KolmogorovSmirnov two samples (one-tailed or two-tailed) tests ${ }^{12}$ ) and chi-square tests were used for examining difference or agreement among distributions of age of the respondents in each class of noise levels.

\section{RESULTS}

4.1 Subjective Ratings of Health State Analyzed by the Quantification Method

Table 4 shows estimated (or quantified) values representing health state for each category of the items (or factors). In this table, plus values means worse health state than the average of the estimated values for health state of the whole respondents. It also shows partial correlation of each item and 
T. YOSHIDA and S. NAKAMURA: HEALTH STATE AND RAILWAY NOISE

Table 4 Results of the analysis by the quantification method II $(r=0.305)$.

\begin{tabular}{|c|c|c|c|c|}
\hline $\begin{array}{c}\text { Items } \\
\text { (factors) }\end{array}$ & Category & $\begin{array}{l}\text { Estimated } \\
\text { values }\end{array}$ & Range & $\begin{array}{l}\text { Partial } \\
\text { correlation }\end{array}$ \\
\hline \multirow{5}{*}{ Age (years) } & $\sim 29$ & -1.01 & 1.72 & 0.197 \\
\hline & $30 \sim 39$ & -0.90 & & \\
\hline & $40 \sim 49$ & -0.33 & & \\
\hline & $50 \sim 59$ & 0.21 & & \\
\hline & $60 \sim$ & 0.71 & & \\
\hline \multirow{4}{*}{$\begin{array}{l}\text { Noise Level } \\
\left(L_{\mathrm{dn}}, \mathrm{dB}(\mathrm{A})\right)\end{array}$} & $30 \sim 49$ & -0.37 & 1.14 & 0.113 \\
\hline & $50 \sim 59$ & 0.13 & & \\
\hline & $60 \sim 69$ & 0.23 & & \\
\hline & $70 \sim 79$ & 0.77 & & \\
\hline \multirow{3}{*}{ Occupation } & Full-timers & -0.82 & 0.98 & 0.106 \\
\hline & Part-timers & -0.15 & & \\
\hline & No. occup. & 0.16 & & \\
\hline \multirow{4}{*}{$\begin{array}{l}\text { Occupation of } \\
\text { husband }\end{array}$} & Labour & -0.44 & 0.77 & 0.079 \\
\hline & CIS \& Bus. & -0.07 & & \\
\hline & Professional & 0.31 & & \\
\hline & No occup. & 0.33 & & \\
\hline \multirow{2}{*}{ Tracks of RW } & SD & -0.18 & 0.47 & 0.079 \\
\hline & TW & 0.29 & & \\
\hline
\end{tabular}

Abb. CIS: commercial and industrial workers and service men except Labourers, Bus.: business men, SD: single or pair tracks of railways, TW: two pairs. RW: railways.

correlation ratio was 0.305 that was statistically significant $(p<0.01)$. It is also found in this table that dominant items (or factors) were age, noise levels and occupation, since these variables indicated higher partial correlations and wider ranges of estimated values than the others predictor items. Figures 1 and 2 show the estimated values for the factors of age and noise levels respectively. These figures demonstrate that greater age and higher levels of noise increased ill-health. Noise levels $\left(L_{\mathrm{dn}}\right)$ were highly related to estimated values of health state $(E V H S)$ in regression given by $E V H S=-1.60+$ $0.0305 \cdot L_{\mathrm{dn}}(r=0.975)$. Age $(A G)$ were also highly related to estimated values of health state in regression given by $E V H S=-2.31+0.0454 \cdot A G$ $(r=0.984)$. As for the categories of occupation, "full-time workers" indicated a trend to goodhealth, whereas "no occupation" indicated a trend to ill-health. As for the categories of occupation of their husbands, "no occupation" or "professionals" indicated a trend to ill-health, while "labourers" had a trend to good-health. As for tracks of railways, "single track or double tracks" showed a trend to good health, while "two pairs of tracks" had a trend to ill-health.

\subsection{Subjective Ratings of Health State and Each Objective Disturbance}

Table 5 shows the results of the chi-square tests for examining independence between subjective ratings of health state (SRHS) and answers to each question on objective disturbance, and also shows the proportions (percentages) of ill-health to "highly disturbed" respondents in each question on disturbance. As for awakening due to noise, the proportion of people who said ill-health to respondents who said awakening to be "considerably or extremely often" disturbed due to noise was very high that were statistically different from the proportions of ill-health to respondents who answered to the other categories on awakening $\left(\chi^{2}=30.7, p<0.001\right)$. In the other hand, annoyance indicated no relation to SRHS, and chi-square tests in any ways of partitioning the categories of annoyance and SRHS into 


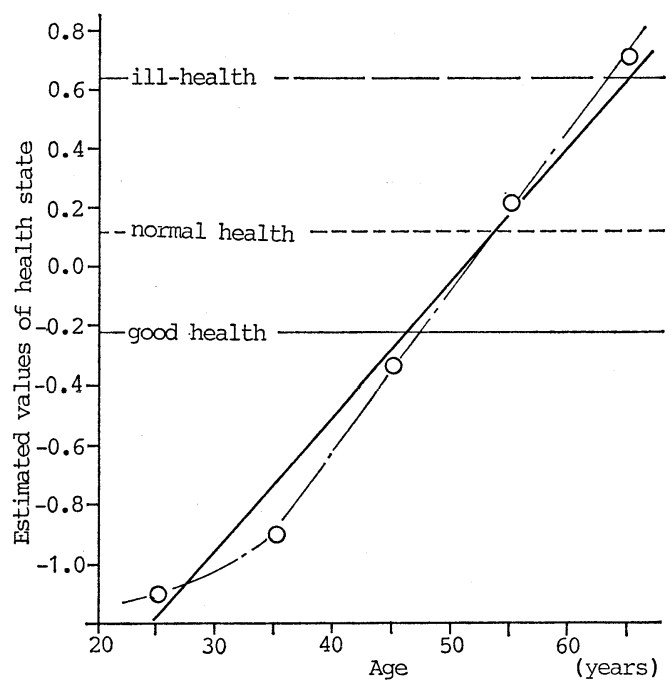

Fig. 1 Estimated values of health state for the factor of age. The words of illhealth, normal health and good health in this figure represent the means of estimated values for each group of ill-health, normal health and good health of the respondents. - : regression line $(E V H S=$ $-2.31+0.0454 A G, \quad r=0.984, \quad E V H S$ : estimated values of health state, $A G$ : years of age). - - - : trend curve.

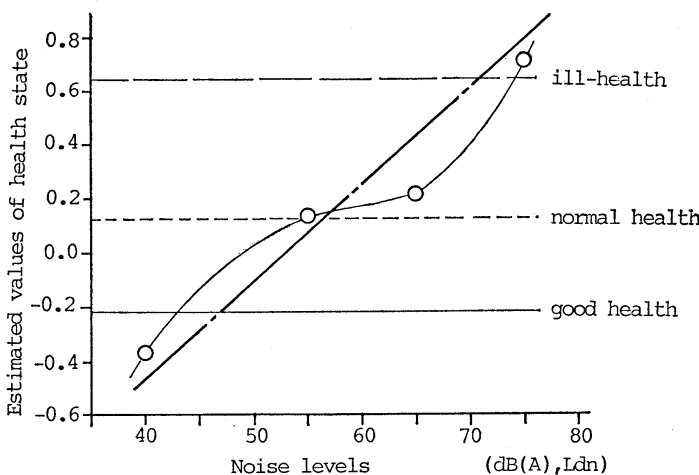

Fig. 2 Estimated values of health state for the factor of noise levels. The words of ill-health, normal health and good health in this figure represent the means of estimated values for each group of ill-health, normal health and good health of the respondents. - : regression line $(E V H S=$ $-1.60+0.0305 L_{\mathrm{dn}}, \quad r=0.975, \quad E V H S$ : estimated values of health state. $L_{\mathrm{dn}}$ : noise levels in $\left.L_{\mathrm{dn}}, \mathrm{dB}(\mathrm{A})\right)$. trend curve.
$2 \times 2$ contingency tables also indicated no statistically significant relationship between annoyance and SRHS at the level of $5 \%$. As for the questions relating to each objective disturbance, it was also found in Table 5 that irritation, gastroenterological disorders, headache or feeling heavy in the head and palpitation of heart indicated very close relations to SRHS $(p<0.001)$. Interference with con-

Table 5 Relation between subjective state of health and each question on objective disturbance.

\begin{tabular}{|c|c|c|c|}
\hline $\begin{array}{l}\text { Questions } \\
\text { on disturbance } \\
\text { due to noise }\end{array}$ & $\begin{array}{l}\text { Definition } \\
\text { of "highly, } \\
\text { bisturbed" } \\
\text { (scale } \\
\text { points) }\end{array}$ & $\begin{array}{c}\text { Percentages } \\
\text { of ill- } \\
\text { health to } \\
\text { "highly } \\
\text { disturbed" } \\
\text { respondents } \\
(\%)\end{array}$ & $\begin{array}{l}\text { Chi- } \\
\text { square } \\
\text { test }\end{array}$ \\
\hline Annoyance & $6+7(7)$ & 13.0 & 0.04 \\
\hline $\begin{array}{l}\text { Dissatisfaction } \\
\text { with noise environ. }\end{array}$ & $4(4)$ & 13.6 & 0.89 \\
\hline $\begin{array}{l}\text { Interference with } \\
\text { listening to TV }\end{array}$ & $4+5(5)$ & 16.4 & $4.23^{*}$ \\
\hline General disturbance & $4(4)$ & 18.5 & $4.34 *$ \\
\hline $\begin{array}{l}\text { Difficulty in } \\
\text { thinking/reading }\end{array}$ & $4+5(5)$ & 36.4 & $4.74^{*}$ \\
\hline Difficulty in relaxing & $4+5(5)$ & 31.6 & $6.14^{*}$ \\
\hline $\begin{array}{l}\text { Interference } \\
\text { with telephoning }\end{array}$ & $4+5(5)$ & 20.3 & $6.16^{*}$ \\
\hline Startle & $4+5(5)$ & 33.3 & $8.42 * *$ \\
\hline $\begin{array}{l}\text { Difficulty in } \\
\text { getting to sleep }\end{array}$ & $4+5(5)$ & 36.8 & $10.32 * *$ \\
\hline Earache or tinnitus & $4+5(5)$ & 57.1 & $10.67 * * *$ \\
\hline Palpitation & $4+5(5)$ & 66.7 & $13.45 * * *$ \\
\hline $\begin{array}{l}\text { Interference } \\
\text { with conversation }\end{array}$ & $4+5(5)$ & 26.7 & $13.83^{* * *}$ \\
\hline $\begin{array}{l}\text { Headache or feeling } \\
\text { heavy in the head }\end{array}$ & $4+5(5)$ & 62.5 & $16.45^{* * *}$ \\
\hline $\begin{array}{l}\text { Gastroenterological } \\
\text { disorder }\end{array}$ & $4+5(5)$ & 71.4 & $19.96^{* * *}$ \\
\hline Irritation & $4+5(5)$ & 44.0 & $24.52 * * *$ \\
\hline Awakening & $4+5(5)$ & 44.8 & $30.68 * * *$ \\
\hline
\end{tabular}

Categories of subjective state of health were divided into two categories of "ill-health" and the others. Categories of each question on objective disturbance were also divided into two categories of "highly disturbed" and the others, according to the definitions indicated in the second column from the left. Chisquare tests were conducted with Yetz's correction. The asterisks of $*, * *$ and $* * *$ indicate statistical significance at each level of $p<0.05, p<0.01$ and $p<0.001$ respectively. 


\section{T. YOSHIDA and S. NAKAMURA: HEALTH STATE AND RAILWAY NOISE}

Table 6 Highly disturbed respondents and noise levels $\left(L_{\mathrm{dn}}\right)$ in each question on objective disturbances $(\%)$.

\begin{tabular}{lrrrr}
\hline $\begin{array}{c}\text { Noise levels } \\
(\mathrm{dB}(\mathrm{A}))\end{array}$ & $30 \sim 49$ & $50 \sim 59$ & $60 \sim 69$ & $70 \sim 79$ \\
\hline $\begin{array}{l}\text { Disturbance as a } \\
\text { whole }\end{array}$ & 14.8 & 34.8 & 62.8 & 82.8 \\
Annoyance & 4.0 & 22.1 & 48.7 & 58.6 \\
TV-listening & 1.5 & 13.4 & 43.6 & 58.6 \\
Telephon & 0.3 & 4.8 & 23.1 & 48.3 \\
Conversation & 0.3 & 2.8 & 19.2 & 36.2 \\
Getting to sleep & 0.3 & 0.3 & 5.1 & 15.5 \\
Awakening & 0.0 & 1.7 & 8.3 & 19.0 \\
Irritation & 0.3 & 1.7 & 5.8 & 17.2 \\
Startle & 0.3 & 1.0 & 4.5 & 17.2 \\
Reading \& & & & & \\
$\quad$ thinking & 0.0 & 0.0 & 1.9 & 13.8 \\
Relaxing & 0.3 & 0.7 & 3.2 & 19.0 \\
Gastroenter. & & & & \\
$\quad$ disorder & 0.0 & 0.0 & 1.3 & 8.6 \\
Tinnitus \& & & & & \\
$\quad$ earache & 0.0 & 0.6 & 1.3 & 6.9 \\
Headache \& & & & & \\
$\quad$ heavy-head & 0.6 & 0.6 & 1.3 & 8.6 \\
Palpitation & 0.0 & 0.0 & 0.6 & 8.6 \\
\hline$\quad$ & & & & \\
\hline
\end{tabular}

versation, interference with telephoning, difficulty in getting to sleep, startle and earache or tinnitus indicated rather close relations to SRHS $(p<0.01)$. Disturbance as a whole, dissatisfaction with noise environment, interference with listening to broadcasts, difficulty in thinking or reading and difficulty in relaxing indicated a little relations to SRHS $(p<0.05)$.

In the next, these tendencies were also found in
Table 5 for the proportions of ill-health to "highly disturbed" respondents that were ranged from $13.0 \%$ to $71.9 \%$ according to each question relating to objective disturbance. For example as awakening and SRHS, out of people who answered awakening to be "considerably or extremely often" disturbed due to noise, $44.8 \%$ said that they were of ill-health. The proportions of ill-health for each question on physical symptoms also indicated more than $50 \%$. The proportions for irritation or startle were ranged from $30 \%$ to $45 \%$. These results mean that annoyance have less relation to health state, whereas the other questions relating to sleep disturbance, mental disturbance and physical symptoms have close relation to health state.

Table 6 shows the proportions of "highly disturbed" respondents to the populations in each category of the noise levels. It is found in Table 6 that the proportions of highly disturbed respondents for annoyance, disturbance as a whole and speech interference indicated close relations to noise levels and noise above $50 \mathrm{~dB}(\mathrm{~A})$ increased the proportions of highly disturbed respondents for disturbance as a whole and annoyance. Noise above $60 \mathrm{~dB}(\mathrm{~A})$ also increased clearly the proportions of highly disturbed respondents for speech interference. Sleep disturbance, mental disturbance and physical symptoms increased in the proportions above the noise level of $60 \mathrm{~dB}(\mathrm{~A})$. Especially, noise above $70 \mathrm{~dB}(\mathrm{~A})$ accelerated increase of the proportions for sleep disturbance, mental disturbance and physical symptoms.

Table 7 shows the observed proportions of health state and the expected proportions of health state computed from the distributions of age of the respondents for each class of the noise levels. The

Table 7 Observed and expected proportions (\%) of health state versus noise levels (in $\mathrm{dB}(\mathrm{A})$, $\left.L_{\mathrm{dn}}\right)$.

\begin{tabular}{|c|c|c|c|c|c|c|c|c|c|}
\hline $\begin{array}{l}\text { Noise levels } \\
\text { (samples) }\end{array}$ & $\begin{array}{c}30 \sim 39 \\
(69)\end{array}$ & $\begin{array}{c}40 \sim 44 \\
(83)\end{array}$ & $\begin{array}{l}45 \sim 49 \\
(173)\end{array}$ & $\begin{array}{l}50 \sim 54 \\
(182)\end{array}$ & $\begin{array}{l}55 \sim 59 \\
(109)\end{array}$ & $\begin{array}{c}60 \sim 64 \\
(80)\end{array}$ & $\begin{array}{c}65 \sim 69 \\
(76)\end{array}$ & $\begin{array}{c}70 \sim 79 \\
(58)\end{array}$ & $\begin{array}{l}\text { Total } \\
(830)\end{array}$ \\
\hline $\begin{array}{r}\text { Good-health } \\
\text { (expected) }\end{array}$ & $\begin{array}{c}47.8 \\
(52.3)\end{array}$ & $\begin{array}{l}68.7^{* \mathrm{~m}} \\
(50.9)\end{array}$ & $\begin{array}{c}51.4 \\
(50.3)\end{array}$ & $\begin{array}{l}43.4^{* 1} \\
(48.5)\end{array}$ & $\begin{array}{c}54.1 \\
(50.5)\end{array}$ & $\begin{array}{c}46.3 \\
(49.6)\end{array}$ & $\begin{array}{c}46.1 \\
(48.8)\end{array}$ & $\begin{array}{c}43.1 \\
(48.8)\end{array}$ & 49.9 \\
\hline $\begin{array}{l}\text { Normal-health } \\
\text { (expected) }\end{array}$ & $\begin{array}{c}47.8 \\
(37.8)\end{array}$ & $\begin{array}{l}25.3^{* 1} \\
(38.5)\end{array}$ & $\begin{array}{c}40.5 \\
(38.9)\end{array}$ & $\begin{array}{c}40.1 \\
(39.2)\end{array}$ & $\begin{array}{c}37.6 \\
(39.0)\end{array}$ & $\begin{array}{c}38.8 \\
(38.7)\end{array}$ & $\begin{array}{c}42.1 \\
(39.5)\end{array}$ & $\begin{array}{c}37.9 \\
(39.4)\end{array}$ & 38.9 \\
\hline $\begin{array}{l}\text { Ill-health } \\
\text { (expected) }\end{array}$ & $\begin{array}{l}4.3^{* 1} \\
(9.8)\end{array}$ & $\begin{array}{l}6.0^{* 1} \\
(10.5)\end{array}$ & $\begin{array}{l}8.1^{* 1} \\
(10.7)\end{array}$ & $\begin{array}{l}16.5^{* \mathrm{~m}} \\
(12.1)\end{array}$ & $\begin{array}{c}8.3 \\
(10.5)\end{array}$ & $\begin{array}{c}15.0 \\
(11.8)\end{array}$ & $\begin{array}{c}11.8 \\
(11.7)\end{array}$ & $\begin{array}{l}19.0^{* \mathrm{~m}} \\
(11.7)\end{array}$ & 11.2 \\
\hline
\end{tabular}

Expected proportions were computed from the data of age distributions (see Table 8). The results of chi-square test for the observed data indicated that health state had some relations to noise levels $\left(\chi^{2}=20.0, f=14, p<0.05\right.$, $* 1$ : lower proportion, ${ }^{* m}$ : higher proportion). 
Table 8 Distributions of age of the respondents in the noise levels, and proportions of illhealth for age.

\begin{tabular}{|c|c|c|c|c|c|c|c|c|c|c|}
\hline \multicolumn{2}{|c|}{$\begin{array}{l}\text { Noise levels } \\
\left(\mathrm{dB}(\mathrm{A}), L_{\mathrm{dn}}\right)\end{array}$} & $30 \sim 39$ & $40 \sim 44$ & $45 \sim 49$ & $50 \sim 54$ & $55 \sim 59$ & $60 \sim 64$ & $65 \sim 69$ & $70 \sim 79$ & $\begin{array}{c}\text { Ill- } \\
\text { health } \\
(\%)\end{array}$ \\
\hline \multirow{5}{*}{$\begin{array}{l}\text { Age } \\
\text { (years) }\end{array}$} & $\begin{array}{c}20 \sim 29 \\
(\%)\end{array}$ & $\left(\begin{array}{l}5 \\
7.2)\end{array}\right.$ & $\begin{array}{l}4 \\
(4.8)\end{array}$ & $\stackrel{14}{(8.1)}$ & $\begin{array}{l}11 \\
(6.0)\end{array}$ & $\begin{array}{l}7 \\
(6.4)\end{array}$ & $\left(\begin{array}{l}0 \\
0.0\end{array}\right)$ & $\begin{array}{l}3 \\
(3.9)\end{array}$ & $\begin{array}{l}4 \\
(6.9)\end{array}$ & 2.1 \\
\hline & $\begin{array}{c}30 \sim 39 \\
(\%)\end{array}$ & $\begin{array}{c}9 \\
(13.0)\end{array}$ & $\begin{array}{l}10 \\
(12.0)\end{array}$ & $\begin{array}{l}29 \\
(16.8)\end{array}$ & $\begin{array}{l}23 \\
(12.6)\end{array}$ & $\begin{array}{l}18 \\
(16.5)\end{array}$ & $\begin{array}{l}15 \\
(18.8)\end{array}$ & $\begin{array}{l}10 \\
(13.2)\end{array}$ & $\begin{array}{c}6 \\
(10.3)\end{array}$ & 3.3 \\
\hline & $\begin{array}{c}40 \sim 49 \\
(\%)\end{array}$ & $\begin{array}{l}24 \\
(34.8)\end{array}$ & $\begin{array}{l}28 \\
(33.7)\end{array}$ & $\begin{array}{l}39 \\
(22.5)\end{array}$ & $\begin{array}{l}28 \\
(15.4)\end{array}$ & $\begin{array}{l}30 \\
(27.5)\end{array}$ & $\begin{array}{l}14 \\
(17.5)\end{array}$ & $\begin{array}{l}18 \\
(23.7)\end{array}$ & $\begin{array}{l}13 \\
(22.4)\end{array}$ & 6.2 \\
\hline & $\begin{array}{c}50 \sim 59 \\
(\%)\end{array}$ & $\begin{array}{l}18 \\
(26.1)\end{array}$ & $\begin{array}{l}21 \\
(25.3)\end{array}$ & $\begin{array}{c}37 \\
(21.4)\end{array}$ & $\begin{array}{c}59 \\
(32.4)\end{array}$ & $\begin{array}{c}21 \\
(19.3)\end{array}$ & $\begin{array}{l}30 \\
(37.5)\end{array}$ & $\begin{array}{l}19 \\
(25.0)\end{array}$ & $\begin{array}{l}15 \\
(25.9)\end{array}$ & 14.5 \\
\hline & $60 \geqq$ & $\begin{array}{l}13 \\
(18.8)\end{array}$ & $\begin{array}{l}20 \\
(24.1)\end{array}$ & $\begin{array}{c}54 \\
(31.2)\end{array}$ & $\begin{array}{l}61 \\
(33.5)\end{array}$ & $\begin{array}{l}33 \\
(30.3)\end{array}$ & $\begin{array}{l}21 \\
(26.3)\end{array}$ & $\begin{array}{l}26 \\
(34.2)\end{array}$ & $\begin{array}{l}20 \\
(34.5)\end{array}$ & 17.7 \\
\hline
\end{tabular}

The results of Kolmogorov-Smirnov two-samples tests showed some discrepancies of age distributions between $50 \sim 54 \mathrm{~dB}(\mathrm{~A})$ and $30 \sim 39,45 \sim 49$ or $55 \sim 59 \mathrm{~dB}(\mathrm{~A})$ of the noise levels $(p<0.05)$. These discrepancies were due to differences of the frequencies of age in $40 \sim 49$ and $50 \sim 59$ years between $50 \sim 54 \mathrm{~dB}(\mathrm{~A})$ and $30 \sim 39,45 \sim 49$ or $55 \sim$ $59 \mathrm{~dB}(\mathrm{~A})$ of the noise levels.

results of chi-square test for the contingency table of the observed data (shown in Table 7) indicated some relations between the proportions of health state and noise levels. The noise lower than $50 \mathrm{~dB}(\mathrm{~A})$ showed lower proportions of ill-health, whereas the noise in $50 \sim 54$ and $70 \sim 79 \mathrm{~dB}(\mathrm{~A})$ showed higher proportions of ill-health. But the results were obtained in taking no account of distribution of age. So the effects of age will be examined as follows.

Table 8 shows the distributions of age versus the noise levels. Kolmogorov-Smirnov two-samples tests showed some discrepancies of age distributions between $50 \sim 54 \mathrm{~dB}(\mathrm{~A})$ and $30 \sim 39,45 \sim 49$ or $55 \sim$ $59 \mathrm{~dB}(\mathrm{~A})$ of the noise levels. In spite of these tendencies of age distributions among noise levels, the expected proportions of health state (Table 7) computed from the age distributions shown in Table 8 were rather same to each other. These suggests that the results obtained only from the observed data in Table 7 were affected in a part by the distributions of age of the respondents. Then the decrease of ill-health in the noise of $50 \sim 54 \mathrm{~dB}(\mathrm{~A})$ seems to be uncertain, as far as taking account of the results of Tables 7 and 8.

Figure 3 shows the relationship of the proportion of ill-health and the proportion of age older than 50 years that obtained from Tables 7 and 8 . The proportion of ill-health had clear relation to the proportion of age older than 50 years, except the proportion of ill-health in $70 \sim 79 \mathrm{~dB}(\mathrm{~A})$ of the noise. The proportion of ill-health in $70 \sim 79 \mathrm{~dB}(\mathrm{~A})$ of the

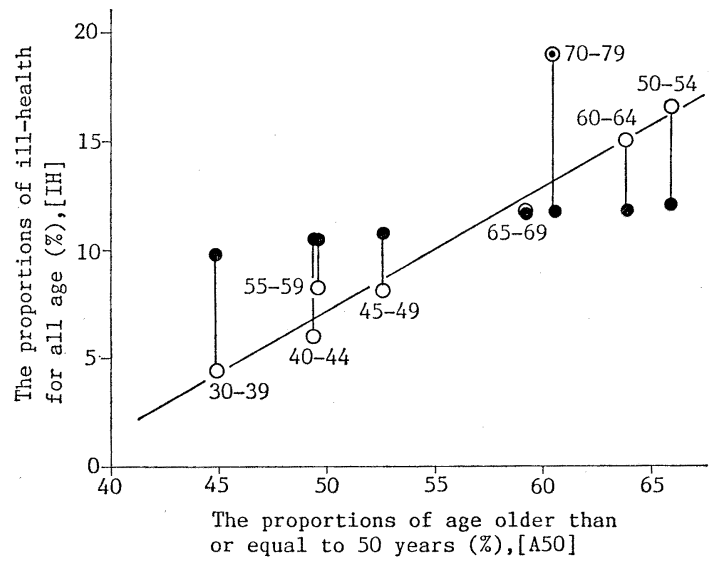

Fig. 3 The proportions of ill-health for all age versus the proportions of age older than or equal to 50 years, for each class of the noise levels. Circles show the observed proportions of ill-health for all age and dotts show the expected proportions of ill-health computed from the age distributions in Table 8 . Numbers in this figure indicate the classes of the noise levels. Solid line shows the regression in $[\mathrm{IH}]=-21.0+0.563$ [A50] (except the data shown in $\odot, r=0.987$ ).

noise showed rather large difference from the regression line (solid line in Fig. 3) and the difference of ill-health in $70 \sim 79 \mathrm{~dB}(\mathrm{~A})$ was large between the observed proportion and the proportion computed 


\section{T. YOSHIDA and S. NAKAMURA: HEALTH STATE AND RAILWAY NOISE}

from the age distributions. Further, the distribution of age in $70 \sim 79 \mathrm{~dB}(\mathrm{~A})$ of the noise showed no difference from any distributions of age in the other noise levels in the results of Kolmogorov-Smirnov tests for Table 8 . Then, it would be rather sure that the noise in $70 \sim 79 \mathrm{~dB}(\mathrm{~A})$ led higher proportion of ill-health, as the results of the quantification showed that older age and higher levels of noise led to increase ill-health. So the results of the quantification method was clearer than the results obtained from Tables 7 and 8 and Fig. 3, because this results were obtained in taking account of the factors of age, noise levels, occupation of themselves, occupation of their husbands and numbers of tracks of railways.

\section{DISCUSSION}

Effects of age on health state is considered to be a general fact. ${ }^{13)}$ The results in Table 4 showed that higher levels of noise increased ill-health as well as did older age (Figs. 1 and 2). This would mean that noise could affects health state. As for effects of noise levels on health state, several studies have been published especially on aircraft noise. For example, Tarnopolsky et al. (1980) reported that most of the people who complain of aircraft noise were psychiatrically normal and most of the psychiatric cases were free of annoyance. ${ }^{1)}$ Kryter mentioned by quoting from Koszarny et al. (1981) that significantly greater numbers of complaints related the cardiovascular system, the digestive system, frequency of taking medication for heart problems or headaches, and nervousness were found in women living in a higher noise area than in a lower noise level area. ${ }^{14,15)}$ The results of this study seem to resemble in a meaning to the results of these researches, although this study does not concerned to psychiatrical disorders. These suggests that sleep disturbance and irritation et al. due to noise would lead to autonomic-system stress responses and would lead to ill-health. ${ }^{15)}$

Table 6 demonstrates that the noise above 60 $\mathrm{dB}(\mathrm{A})$ increased "highly disturbed" respondents to sleep disturbance, mental disturbance and physical symptoms as well as speech interference. By the way, Knipschild (1977) demonstrated that the people living in $L_{\mathrm{dn}}>60$ suffered from more health disorders in general than do people in $L_{\mathrm{dn}}<60$ in the view points of physician contact in relation to aircraft noise. ${ }^{16)}$ The results of this study resemble to this Knipschild's results, although this study did not concerned to physician contact.

In conclusion, it is found in Fig. 2 that the average of estimated value of health state for the noise levels of $70 \sim 79 \mathrm{~dB}(\mathrm{~A})$ is very different from that for the noise levels of $60 \sim 69 \mathrm{~dB}(\mathrm{~A})$, and that $75 \mathrm{~dB}(\mathrm{~A})$ is approximately same to the noise level corresponded to the average of estimated values for the population of ill-health. Further, noise level of partitioning the categories into normal-health and ill-health corresponded roughly to $70 \mathrm{~dB}(\mathrm{~A})$ in the results of the analysis by the quantification method (Fig. 2), and noise above $70 \mathrm{~dB}(\mathrm{~A})$ accelerated increase of the proportions of ill-health to the highly disturbed respondents (Table 5, Fig. 3). Therefore, a critical noise level of accelerating increase of ill-health would be considered to be $70 \mathrm{~dB}(\mathrm{~A})$ in $L_{\mathrm{dn}}$.

Many interesting results were obtained in this study, but further researches should be conducted on health state in relation to noise, especially in taking account of socio-economical factors.

\section{CONCLUSION}

1) Subjective ratings of health state were interpreted mainly by age, noise levels, occupation, occupation of husbands and tracks of railways.

2) Greater age and higher noise levels increased ill-health.

3) Annoyance had no relation to subjective ratings of health state, whereas awakening, irritation and physical symptoms showed close relation to subjective ratings of health state.

4) Noise above $60 \mathrm{~dB}(\mathrm{~A})\left(L_{\mathrm{dn}}\right)$ increased the proportions of highly disturbed respondents for sleep disturbance, mental disturbance and physical symptoms as well as annoyance and speech interference.

5) $70 \mathrm{~dB}(\mathrm{~A})\left(L_{\mathrm{dn}}\right)$ would be a critical noise level of accelerating increase of ill-health and highly disturbed respondents.

\section{ACKNOWLEDGEMENTS}

In a view point of subjective ratings of health state, the authors reanalyzed the data from "Community Responses to Noise in Near-Area of Railways" that was carried out by the committee of Y. Osada (chairman), A. Tamura, T. Yoshida and T. Mochizuki (management), and N. Imaizumi, S. Nakamura, and Y. Uehara of The Tokyo Metropolitan Research Institute for Environmental Pro- 
tection in the projects of 1983. The authors wish to acknowledge Y. Osada for his encouragement and advices. The authors also wish to acknowledge all members of this project. The many parts of the results of this project was reported in Ref. 7) and 17).

\section{REFERENCES}

1) A. Tarnopolsky, D. J. Hand, S. M. Barker, and L. M. Jenkins, "Aircraft noise, annoyance, and mental health: A psychiatric viewpoint," Proc. 3rd Int. Congr. Noise as a Public Health Problem, ASHA Rep. 10, 588-593 (1980).

2) P. Knipschild, "Aircraft noise and hypertension," Proc. 3rd Int. Congr. Noise as a Public Health Problem, ASHA Rep. 10, 283-287 (1980).

3) E. Grandjean, P. Graf, A. Lauber, H. P. Meier, and R. Muller, "Survey on the effects of aircraft noise around three civil airports in Switzerland," Proc. Inter-Noise '76, 85-90 (1976).

4) E. Gros, B. Griefahnand, and D. Lang, "Sleep disturbance caused by noise: Analysis of a crosssectional inquiry," Proc. 4th Int. Congr. Noise as a Public Health Problem, Edizioni Tec. CRSA, II, 905-915 (1983).

5) J. Francois, "Aircraft noise, annoyance, and personal characteristics," Proc. 3rd Int. Congr. Noise as a Public Health Problem, ASHA Rep. 10, 594-599 (1980).

6) D. J. Hand, A. Tarnopolsky, and S. A. Barker, "Relationships between psychiatric hospital admissions and aircraft noise: A new study," Proc. Int. Congr. Noise as a Public Health Problem, ASHA
Rep. 10, 277-282 (1980).

7) S. Nakamura, "Community response of noise in near area of railway," Noise Control (INCE/ JAPAN) 9(6), 314-319 (1985) (in Japanese).

8) Y. Ando and H. Hattori, "Statistical studies of the effects of intense noise during human fetal life," J. Sound Vib. 27, 101-110 (1973).

9) S. Yasuda, Social Statistics (Maruzen, Tokyo, 1969), pp. 194-201 (in Japanese).

10) T. Komazawa, Quantification Method and Data Analyses (Asakura-shoten, Tokyo, 1982), pp. 4988 (in Japanese).

11) S. Siegel, Nonparametric Statistics for the Behavioral Sciences (McGraw-Hill, New York, 1956), pp. 6167.

12) S. Siegel, Nonparametric Statistics for the Behavioral Science (McGraw-Hill, New York, 1956), pp. 127136.

13) K. Morimoto, "Life-style and health," Public Health 51(2), 135-143 (1987) (in Japanese).

14) Z. Koszarny, S. Maziarka, and W. Szata, "The effect of airplane noise on the inhabitants of areas near the Okecie Airport in Warsaw," in Effects of Noise, K. D. Kryter, Ed. (Academic Press, New York, 1985), p. 490.

15) K. D. Kryter, Effects of Noise (Academic Press, New York, 1985), p. 482.

16) P. Knipschild, "Medical effects of aircraft noise: General practice survey," Int. Arch. Occup. Environ. Health 40(3), 191-196 (1977).

17) S. Nakamura, Y. Uehara, and N. Imaizumi, "Community responses to noise in near-area of railways," Annu. Rep. Tokyo Metrop. Res. Inst. for Environmental Protection, 155-185 (1985). 